\title{
THE STRATEGIES OF AL-ISTIQOMAH NGATA BARU MODERN ISLAMIC BOARDING SCHOOLIN APPLYING ENGLISH SPEAKING SKILL TO SANTRI
}

\author{
Abdul Latif Fajar Mokodompit \\ Yuni Amelia \\ English Tadris Study Program, Faculty of Tarbiyah and Teacher Training \\ State Institute for Islamic Studies Palu
}

\begin{abstract}
In improving the English language skills of students, the Pondok Pesantren modern Al-istiqamah Ngata Baru has a language strategy. Students are required to communicate using English. However, in fact there are still some students whose English is still weak and left behind. The purpose of this study was to determine the strategy of the modern Al-istiqamah Ngata Baru Islamic boarding school in applying the speaking skills of the students.

This research is used qualitative research. The research subjects were the head of the language field, the English teacher, the dormitory musyrif, the CLI (Central Language Improvement) board, and the students of the Al-istiqamah Ngata Baru Modern Islamic Boarding School. The technique used in determining the research subject is purposive sampling technique. Data collection techniques by interview, observation, and documentation. The data analysis techniques used were data collection, data reduction, data presentation, and verification.

The results of this study indicate that the application of the strategy in English at Pondok Pesantren Modern Al-istiqamah Ngata Baru has been going well. With the English language strategy, the students 'English language skills continue to improve and with it the students understand better the lessons in class and the students' achievement increases, and they are able to win the English competition.
\end{abstract}

Key words: English Language Strategy, English Language Ability 


\section{Introduction}

Pesantren (Islamic Boarding

School) is an institution that focuses on religious education and activities. It enhances students' capabilities and abilities mainly in Islamic aspects. Pesantren as a religious institution, functions to teach, develop and disseminate Islamic religious knowledge to students ${ }^{1}$. Pesantren as an Islamic educational institution is also a traditional education in which students, called santri, live together and study under the guidance of teachers who are better known as "kiai" and have dormitory/ies for students to stay. The santri are located in a complex which also provides a mosque for worship, a space for studying, and other religious activities ${ }^{2}$.

As time went on, many pesantren reconstructed the existing education model, including updating the curriculum, by teaching science outside religious education, in this case, a foreign language, namely English. Pesantren is seen as modernizing its education system, and this dynamic shows the kindness of the process. Pesantren are considered capable of competing with other educational institutions under the auspices of the Ministry of National Education and the Ministry of Religion ${ }^{3}$. In a modern pesantren environment, students are required to get used to using several languages that have become standard as a means of communication. The learning system in pesantren applies the habit of using Indonesian, Arabic, and English in

${ }^{1}$ Mi'ah, A. (2013). Pemikiran

Nurcholis Madjid tentang Modernisasi Sistem Pesantren [UIN Sunan Ampel]. http://digilib.uinsby.ac.id/10378/

${ }^{2}$ Risdianto, F. (IAIN S. (2016). Model Pembelajaran Bahasa Inggris di Ponpes Ta'mirul Islam Surakarta.

Leksema, 1(1), 47-58.

http://ejournal.iainsurakarta.ac.id/index.ph p/leksema/article/download/24/40

$$
{ }^{3} \mathrm{lbid}
$$

everyday communication. With foreign language skills adequate, it is hoped that students can compete when they have graduated and are ready to benefit in society.

Almost all Islamic boarding schools in Indonesia have obliged their students master foreign languages, especially Arabic and English ${ }^{4}$ The same is applied by Al-Istiqamah Ngata Baru, a Modern Islamic Boarding School founded by KH. Muhammad Arif Siraj LC, on May $2^{\text {nd }} 1993$ in Ngata Baru, Central Sulawesi, that follows Gontor Islamic Boarding School for its language learning system. AtAl-istiqamah Ngata Baru, students are obligated to use English and Arabic in their daily activities with a program namely Weekly Language .

Al-istiqomah Ngata Baruuses Indonesian, English and Arabic as foreign languages in their daily communication. The foreign languages learning strategy is an interesting topic to have further research. The writers are interested to English, because this Pesantren is widely known for its English. So, this research focused on components of teaching learning process used on daily communication. Strategies of English teaching in Modern Islamic Boarding School is believed inresulting students's ability in speaking.

Therefore, to have further knowledge related to pesantren used strategies in teaching its students English, the writers conducted a research entitled "English at Pesantren; The Strategies of

\section{${ }^{4}$ Anto, Puji ; Rahman, F. (2018).}

Bahasa, Jasus Bahasa: Suatu Metode Pembelajaran dalam, Asing di Pesantren Modern (Representasi Gontor), Novel Berlatar Pondok Modern. Prosiding Pekan Seminar Nasional (Pesona) 2018. https://journal.uhamka.ac.id/index.php/pes ona/article/download/2354/682/ 


\section{Al-Istiqomah Ngata Baru Modern Islamic Boarding Schoolin Applying English Speaking Skillto Santri”}

\section{Previous Studies}

Similar researches found to support this study on English at pesantren topic. Strategies of the English Teacher in Islamic Boarding School (IBS). This study analyzed how the teacher strategies teaching in Islamic Boarding School. In this research motivation of the teachers in IBS to teaching English divided into three themes or reasons. First, passion, for this reason, the pure teacher should have the intention as a teacher, because comfortable teaching then the teacher makes teaching as a profession. Second, comfortable and interesting working. This reasoning leads to an environment where teachers teach. Both the physical environment such as teacher's work environment and the atmosphere within the school. The result of this study saythat there are factors that influence in determining the strategy be used by English teachers, such as teachers' educational background, students' enthusiasm level or students' motivation, teachers' understanding of the student's character, and regulations applied in IBS. English teachers in several IBSs try creative ways to develop the strategies they use in teaching English, yet stagnant strategies are still being used to suit students' needs ${ }^{5}$. It proves that the renewal of teaching strategies, old ways are not entirely unnecessary.

English Learning in Islamic Boarding School Al-Junaidiyah Biru Bone (Ethnnographic Studies).This study is Ethnography by using qualitative approach and based on the research findings, it can be concluded that (1)analyzing the needs and environmental context in the formulation of learning objectives, (2) using 2 curriculum that is the curriculum

\footnotetext{
${ }^{5}$ Ariskah Putri Lestari, Strategies of the English Teacher in Islamic Boarding School (IBS), Atlantis Pers 317, (2009): 5
}

of 2013 special subjects andthe curriculum of special pesantren religious subjects, (3) adjustment of learning materials with context, social function, text structure, and linguistic elements, (4) using approach (Contextual Teaching and LearningCTL),(5) Educators, and learners have an interconnected role of learning to be interesting and fun, (6) developed languages such as the implementation of English flag ceremonies, sports competitions, and arts that use English in extracurricular activities ${ }^{6}$.

\section{English Learning System in Islamic} Boarding School. This research is describing the real description about English learning system in SMP Plus AlAqsho. This research uses qualitative research design This research intends to find out: (1) the English learning system in SMP Plus Al-Aqsha Islamic Boarding School, (2) the output of the teaching of English learning system in SMP Plus AlAqsha Islamic Boarding School, and (3) the supporting factors and obstacles in achieving the effectiveness of English learning system at SMP Plus Al-Aqsha Islamic Boarding School. The result of this study says This research finds that qualification level of SMP Plus Al-Aqsha (Junior High School) is equal with SLTP. The equal level here does not mean the same, because the substance of SMP Plus Al-Aqsha contains two education systems, which are SMP (Junior High School) and KMMI (Kulliyat al-Muallimin wa alMuallimat al-Islamiyah) that can be decoded by Islamic boarding school.The process of teaching learning in SMP Plus Al-Aqsha is the same with other junior

${ }^{6}$ Suardi, Suardi; Emzir; Rafi, Z. (2017). English Learning in Islamic Boarding School Al-Junaidiyah Biru Bone (Ethnographic Studies). Journal of

Education Teaching and Learning, 2(2), 224-227.

https://doi.org/https://www.researchgate.ne t/deref/http\%3A\%2F\%2Fdx.doi.org\%2F10 .26737\%2Fjetl.v2i2.290 
high schools, either in the lesson plans or the syllables. The process of teaching learning which covers the four skills of English-listening, speaking, reading, and writing. It is added by the activities held under the curriculum of KMMI, such as English conversation, English vocabulary and speech practice. With this system, the score or achievement index, expecially English subject, the students are able to comprehend the material so that they get score in average of students' score exceed the standar from KKM. From the research, it also can be concluded that the supporting factor in learning English is the additional English subject under curriculum of KMMI, while the obstacle is the congest schedule. From the result above, the writer suggests A teacher must be very clever to motivate students to study hard, to decrease the laziness of students. Time is very important for student to learn. School has to re-arrange the students schedule to not make them too tired.

\section{Research Methods}

This is a qualitative research to analyze the strategies of modern islamic boarding school Al-istiqamah Ngata Baru. Qualitative research is an approach to study of social phenomenon; its various genre is naturalistic and interpretative, and they draw on multiple methods of inquiry. Some charateristics of qualitative research are; take places in the natural world, use multiple methods that are interactive and humanistic. ${ }^{7}$ Besides, this research also focused on descriptive qualitative method. Descriptive method has not purpose to test the certain hypothesis, but just describes some variable and condition naturally.

The object of this research is the ninth-Grade students at Al-istiqmah Boarding School, the leaders of its boarding school and the English teachers.

${ }^{7}$ Marshall, The Case for Combining Qualitative and Quantitative Approaches in Health Service Research, (1999:2).
The researcher collected the data in the forms of primary source data and secondary source data. Primary source data is source of data which is related to the subject of this study that is taken through the researcher directly. In this research primary data sourch came from the conducting of observation and interview with the subject of this research such as, student, manager, and lead of modern boarding school. Besides, secondary data source is a source of the data that is taken by the researcher indirectly from the subject. It was relevant book, from the journals, journal of school, school archives about the history of school, and the other source that relevant to support this research.

\section{Data Collection}

The procedures of collecting data; Observation, and Interview. Observation is a form of conscious effort to collect data carried out systematically, with standardized procedures. To find out the extent of the process of learning English in the Modern Islamic boarding school Alistiqamah Ngata Baru, it is necessary to see and pay attention to the process of activities carried out by students in the dormitory and in what classes are aspects of the Al-istiqamah boarding school in improving speaking skills. Interview, was done with the head of the language sector, musyrif / ustadz in the dormitory, class teachers, and several students in the dormitory. After publishing a number of things which according toresearchers are important, they are evaluated to find conflicts and solutions to these conflicts.

\section{Data Analysis}

In this study, to analyze the data that has been obtained is a descriptive (non-statistical) way, that is, the research is carried out by describing the data obtained with words or sentences separated for categories. To obtain the conclusions meant to find out the state of something 
about what and how, how much, to what extent and so on.

In connection with this study, researchers used interaction analysis models or interactive analysis models with the steps taken as follows:

a. Data Collection

Conducted by searching the data needed for various types of data and forms of data in the field, then carry out recording data in the field.

b. Data reduction

If the data has been collected the next step is to reduce the data. Reducing data means summarizing, choosing the main points, focusing on the important things, looking for themes and patterns and removing unnecessary. Thus, the reduced data will provide a clearer picture, and make it easier for researchers to do further data collection and look for it if necessary.

\section{c. Data Presentation}

In this case Miles and Huberman said that in qualitative research, the presentation of data can be done in the form of brief descriptions, charts, relationships between categories, flowcharts, and the like. The most often used to present data is narrative text. ${ }^{8}$ While the data has been reduced and classified according to the group of problems studied, making it possible to draw conclusions or verify the learning strategies that exist in the modern Islamic boarding school Alistiqamah Ngata Baru.

d. Verification

After the data is presented, the next step is to draw conclusions based on data reduction which is the answer to the problem raised in the study. Verification is a series of peak data analysis. However,conclusions also

\footnotetext{
${ }^{8}$ Sugiyono,

MemahamiPenelitianKualitatif, (Bandung:

Alfabeta,2016), 341.
}

require verification throughout the study. Verification is intended to get a valid conclusion. Therefore, it is better if a conclusion is reviewed by reverifying the notes during the study and looking for patterns, themes, models, relationships, and similarities to draw a conclusion. ${ }^{9}$

\section{Research Findings and Discussion}

Ngatabaru is one of the villages located $\pm 14 \mathrm{Km}$ to the south level of Palu City with a radius of $4 \mathrm{Km}$ from the housing population of Petobo Village. Precisely the village is located in the highlands of the Bulili mountains. At that time, Ngatabaru village was a nonproductive area due to its high altitude, and unfriendly land for agriculture or plantations. Coupled with a small spring, then the area is only able to grow plants that are resistant to drought.In this place precisely on May 2, 1993 KH. Muhammad Arif Siraj, Lc began "Babat Alas" to establish Al-Istiqamah Modern Islamic Boarding School on a \pm 3 ha private land. Actually, its establishment plan has been pioneered since March 1993, as a strong intention to realize the ideals of "A Thousand Gontor" in Indonesia.

Al-Istiqamah Modern Islamic Boarding School does not recognize the dichotomy between religion and general science, but both are fully integrated and taught with a comparison of $100 \%$ religious knowledge and $100 \%$ general science. While teaching methods in the field of religious knowledge and foreign languages (Arabic and English) using the direct method (direct method) without translation into Indonesian or other languages.

PondokPesantren Modern Alistiqamah Ngata Baru is an educational institution that combines two curricula, general (Diknas) and religion (pesantren) in effective learning days and hours. In this

\footnotetext{
${ }^{9}$ S.Nasution,Metode Research, ( Jakarta:Bumi Aksara,2007), 130.
} 
case the researcher will discuss more about one of the programs of the pesantren curriculum, one of the programs of the pesantren curriculum, namely the English language development program. The Ngata Baru Al-istiqamah Modern Islamic Boarding School has high hopes that its students can become intellectual and intellectual scholars, therefore the students must be able to master the international language, which is English.

In everyday life, students are required to use English according to the language week, so the pondok has special language regulations or it can be said to have a language system. This is as conveyed by the Leader of Language Advisory Council UstadzSyahrul: "In general, this language system is the same as in other pondok. The compulsory language which for new first grade students we still have a probation period of 6 months so we are not obliged to speak, only after more than 6 months it is mandatory to speak. Then after 6 months these new children are more focused on Arabic first, maybe English will follow up. For the others, in general there are changes in the times of the week, 2 weeks in Arabic and English, but Arabic is actually more dominant. 2 weeks beginning in Arabic and 2 weeks ending in English each month". ${ }^{10}$

Based on the explanation, it can be seen that the students are really required to used Arabic and English in their dialy basic. This can be seen whenthe students have daily conversations in the dormitory and pondok environment and when they meet asatidz they speak in Arabic or English. It is not easy to discipline the students to get used to using English, because some students do not obey the rules or often violate using Indonesian or worse by using regional languages such as Kaili, Bugis, Javanese, etc., this can be seen when it was found that some of the

\footnotetext{
${ }^{10}$ Syahrul at PondokPesantren Al-istiqamah Ngata Baru at 20 june 2020
}

students used a mixed language, namely English and Indonesian.

Therefore, in order for the language regulation system to run well and achieve the vision of the Pondok's goal, the leader of language advisory collaborated with the asrama musyrif, the Organizer of Central Language Improvement, and the English teacher. This is as conveyed by the Leader of Language Advisory Council, UstadzSyahrul:" Structurally, those who guide activities in the dormitory are Musyrif who are supervised by the CLI management and we as Kabid only instructs CLA regarding the activity program." 11

Every language activity is carried out by the language division of the CLI who gives the instructions to all Musyrif in the dormitory to carry out language activities in the dormitory, and so that the activities run well, every activity in the dorm is also guided by the asrama musyrif or the Asatidz in each hostel. In the existing regulations, students are required to speak English when they are outside the dormitory room and when they are at school, unless it is break time and lunch time, the students are required to use the language again. This is as conveyed by the leader of language advisory council UstadzSyahrul:

"In the dormitory, language is not required when in the room but when the child goes to the bathroom or on the terrace, it is mandatory to speak in the area, here also at school time it is not mandatory to speak so from 7 to 15.00 it is not mandatory to speak except during scout time. When the dhuha prayer or during lunch it is mandatory to speak. In addition, when entering school is not compulsory because in school there is an Indonesian language

\footnotetext{
${ }^{11}$ Syahrul at PondokPesantren Al-istiqamah Ngata Baru at 20 june 2020
} 
subject automatically, we do not oblige it because it contradicts the language system itself."

And so that the students can quickly master the conversation in English, every morning the students are given an additional three mufrodats (vocabulary) in class before lessons at school begin. The person in charge of providing this mufrodat is the IPM management for the language section, so they are the ones who prepare the mufrodat (vocabulary) materials that will be given to the students before entering lessons at school.As stated by leader of language advisory council ustadz Syahrul:

"Additional vocabulary every morning before entering class, so from 06.30 WIB until o'clock. 07.00 WIB is the time to add mufrodats in class. If here, after the Fajr prayer, there is tahfidz first then sports preparation, bathing and other things, only later when it is half past 7 the children are in class for mufrodat. mufrodat and its sentences."

In order for all students to be disciplined in recording the mufrodat, once a week there is a check of the mufrodat notebook, so the students' notebooks are collected at the Musyrif of each dormitory then after that all of these notebooks are reported by the mudabbir to the IPM management in the language section, for students whose records are incomplete then will be given a sentence in the form of a language court. This has been conveyed by the leader of language advisory council, Ustadz Syahrul:"So every morning the addition of mufrodat at night i'adah (repetition), mufrodat and mufrodat notes of the children will be checked and collected to the musyrif of each hostel every Thursday and Friday, when Thursday afternoon their notebooks are collected to IPM via dormitory musyrif and IPM for one day will check what is incomplete, on Saturday it will go to court in such a program. Here there is also muhadatsah (language conversation) so if Monday ta'lim then Thursday is muhadatsah."

To maximize the students' English language skills except adding the mufrodat (vocabulary), the students are also trained in practicing speaking with muhadatsah (conversation), these activities are grouping the students into two people and each group is asked to stand and have a conversation according to the material muhadatsah is conveyed by the musyrif, so before starting muhadatsah, from the musyrif provide muhadatsah material by writing on the blackboard, each student is required to write in his or her own notebook after which the students imitate the correct pronunciation by following the words of the musyrif on duty, After the students mastered the pronunciation of each word and sentence, then each group of two people practiced it by chatting with each other / chatting in a loud voice, and each musyrif would accompany them and correct incorrect conversations so that later the conversation of all the students became correctly according to the pronunciation taught by Musyrif. This Muhadatsah activity is carried out every Thursday morning because students are required to fast every Monday and Thursday, so the students' breakfast time is used for Ta'lim on Monday and muhadatsah on Thursday.

The students are also required to always carried their mufrodat notebook wherever they are and always hold their mufrodat notebook and for students who are caught not carrying will be punished by the CLA and the punishment such as recording mufrodats, or shouting in English, or even push-ups. This is can students discipline in language by always carrying a notebook. It is hoped that they will be able to read vocabulary notes and

\footnotetext{
${ }^{12}$ Syahrul at PondokPesantren Al-istiqamah Ngata Baru at 20 june 2020
} 
example sentences so that they areable to memorize and use them in daily conversations. ${ }^{13}$ This has been conveyed by the leader of language advisory council, Ustadz Syahrul:"Here we are also required to bring a kutayb (small book) or a dictionary, and here there are three levels of books juz 1, 2, and 3 if last year we had to carry the booklet, but starting this semester what we are obliged to do is bring the existing small notebook. their handwriting, which has a mufrodat and is given in the morning, the material is taken from books juz 1,2, and 3. In last year the original printed were we obliged but because so there was written sentences so we obliged to bring only their notebooks. So at least they can read what they have written themselves so we oblige them to bring their own kurosah notes and kutayb / little book 3 juz that we only obliged to have."14

So last year, students were asked to bring the mufrodat book but to make it more optimal, from now on the students are told to bring their mufrodat notebook containing the mufrodat and sample sentences that have been given every morning, but the mufrodat material is still taken from the mufrodat collection book they already have each of the students.For the punishment for students who violate the language in the form of the language court, this activity is carried out after maghrib or dinner time so that the students who enter the court are delayed or ended after the completion of the court. There are two levels of language proficiency which are moderate in that it is carried out in the dormitory along with the dormitory musyrif. They receive moderate punishment for violating with light errors. And for the advanced court conducted at the IPM office in the language section together with the brothers and sisters of the

\footnotetext{
${ }^{13}$ Result of Observasion in Asrama and pondok environment, at 20 june 2020

${ }^{14}$ Syahrul at PondokPesantren Al-istiqamah Ngata Baru at 20 june 2020
}

language section of the IPM board, this punishment is given to students who have frequently entered the court in the dormitory more than three times in a row and this punishment is given to students who violate the language category. severe namely caught speaking in the local language, severe punishmentusually in the form of a bald haircut. This has been conveyed by the leader of language advisory council, Ustadz Syahrul:"In general, the punishment is not a physical one, there are some just like push-ups or we ask to write a mufrodat. And also, we order to them to screaming in English but only when the language court is in progress. So here there is a boarding language court and a CLI court. So, the children who have been in the boarding court by 3 times will get their court up at the CLI court. Unless also if the language has violated it a little bit hard, maybe the local language will go directly to the CLA court, then you can immediately punish the bald head." 15

In the implementation of the court, the provision of punishment is not in the form of severe physical punishment, but is more focused on educational and beneficial punishments such as writing of mufrodats, shouting and walking around of dormitord using by English and other punishments.

Even though language discipline has been implemented and given many kinds of punishments, there are still some students who often violate the rules, but only some students. This was triggered by the interest of the students who lacked awareness of the importance of English for their future. As stated by one of the dormitory Musyrif named Andi Abrar:"So far, there are still many santri who follow the rule, but there are some santri who really deliberately do not speak because they are considered that more challenging,

\footnotetext{
${ }^{15}$ Syahrul at PondokPesantren Al-istiqamah Ngata Baru at 20 june 2020
} 
and gentler for don't used English language." 16

Regarding this problem, the dormitory musyrif found an initiative so that students who often violate can be deterred and don't repeat language violations again, and of course their initiative has been consulted first to the IPM board of the language section, and in a joint deliberation with Asatidz, the dormitory musyrif so that this can be carried out collectively and maximally. As stated by Andi Abrar who served as a musyrif in one of the dormitories, he said"Because there are some students who violently violate this, we took the initiative to raise the court sentence, which we immediately conveyed to the IPM board of language and dormitory musyrif. With this we raise the stages of the court, for example, the first court is still the usual punishment of physical punishment of at least 20 to 30 times push-ups and so it continues from stages one, two, three to four when it is in the fourth stage this court can be reported to the central court and the sentence can be bald."17

The stages of the language regulations at the Modern AlIstiqamahNgtaBaru Islamic Boarding School are:

a. From the leader of language advisory council instructed the CLI and announced the language rules to all dormitory musyrifs, after that the dormitory musyrif inform the members who are in their respective dormitories.

b. Dormitory musyrif as supervisor and controller of language activities in the dormitory

\footnotetext{
${ }^{16}$ Andi Abrar in PondokPesantren Alistiqamah Ngata Baru at 23 june 2020

${ }^{17}$ Andi Abrar in PondokPesantren Alistiqamah Ngata Baru at 23 june 2020
}

c. Every day there will be a language court for students who violate the language rules which are carried out after maghrib, a dormitory musyrif that will give the punishment.

d. Every morning 30 minutes before entering lessons in class, the CLI will provide three new vocabulary words that must be recorded by all students, student notebooks will be collected every Thursday,and students whose records are incomplete will enter the language court.

e. Every Monday morning, the students are obliged to attend language ta'lim in the dormitory with the CLI. And every Thursday morning students are obliged to attend muhadatsah activities in the dormitory.

f. Santri will take a language exam every semester and the results of the exam will be used as the language score on the report card.

Because of many programs it is hoped that they can anlarge their vocabulary, it will make it easier for them to have daily conversations and make it easier for them to understand Englishlanguage lessons. The addition of new vocabulary is carried out every morning in the classroom before the start of school lessons, in each morning they are given an additional three English vocabulary words depending on the week of the languages, so there is a change of language every two weeks, first weeks are using Arabic and two weeks next are using English. In order for this process to run well, checking the vocabulary notebook once a week, and if a student is found whose notes are incomplete, he will be given a penalty. This is done so that students can be diligent in writing vocabulary and be able to use this vocabulary in daily conversation so that their language can improve every day.

Except of gave vocabulary, the students were also given additional 
English lessons at the dormitory, this was done so that to what they said was not only routine but also their grammar could be correct and in accordance with language rules. This activity is carried out by the dormitory musyrif. 


\section{References}

Anto, Puji ; Rahman, F. (2018). Bahasa, Jasus Bahasa: Suatu Metode Pembelajaran dalam, Asing di Pesantren Modern (Representasi Gontor), Novel Berlatar Pondok Modern. Prosiding Pekan Seminar Nasional (Pesona) 2018. https://journal.uhamka.ac.id/index .php/pesona/article/download/235 $4 / 682 /$

Lestari, Ariskah; Pratolo, B. (2019). Series:Advances in Social Science, Education and Humanities Research Proceedings of the First International Conference on Progressive Civil Society (ICONPROCS 2019). First International Conference on Progressive Civil Society (ICONPROCS 2019). https://doi.org/https://doi.org/10.2 991/iconprocs-19.2019.19

Marshall, The Case For Combining Qualitative and Quantitative Approaches In Health Service Research, (1999:2).

Mi'ah, A. (2013). Pemikiran Nurcholis Madjid tentang Modernisasi Sistem Pesantren [UIN Sunan Ampel].

http://digilib.uinsby.ac.id/10378/

Risdianto, F. (IAIN S. (2016). Model Pembelajaran Bahasa Inggris di Ponpes Ta'mirul Islam Surakarta. Leksema, 1(1), 47-58. http://ejournal.iainsurakarta.ac.id/ index.php/leksema/article/downlo $\mathrm{ad} / 24 / 40$

Suardi, Suardi; Emzir; Rafi, Z. (2017). English Learning in Islamic Boarding School Al-Junaidiyah Biru Bone (Ethnographic Studies). Journal of Education Teaching and Learning, 2(2), 224-227. https://doi.org/https://www.resear chgate.net/deref/http\%3A\%2F\%2 Fdx.doi.org\%2F10.26737\%2Fjetl. v2i2.290 